\title{
Relationship between Insulin Binding and Glycogenesis in Cultured Fetal Hepatocytes
}

\author{
P. Menuelle and C. Plas \\ Unité de Recherches sur la Thyroïde et la Régulation Hormonale, INSERM U 96-CNRS ERA 449, Hôpital de Bicêtre, Bicêtre, \\ and Laboratoire Interactions Cellulaires, UER Odontologie, Université Paris 7, Paris, France
}

Summary. Binding of ${ }^{12} \mathrm{I}$ I-insulin and the stimulatory effect of insulin on ${ }^{14} \mathrm{C}$-glucose incorporation into glycogen have been studied in cultured fetal rat hepatocytes. Measurement of both variables was possible at $37^{\circ} \mathrm{C}$ because of the slow rate of insulin degradation in the medium. ${ }^{125} \mathrm{I}$-insulin binding approached maximum after $10 \mathrm{~min}$, thus largely preceding the insulin glycogenic effect which became significant after $45 \mathrm{~min}$. Maximal effect was observed after $3 \mathrm{~h}$ with $10 \mathrm{nmol} / \mathrm{l}$ insulin when 16,000 specific sites per hepatocyte were occupied and half-maximal response was achieved with $0.3 \mathrm{nmol} / \mathrm{l}$ insulin $(2,900$ sites/hepatocyte). Dissociation of bound insulin was rapid $(\mathrm{t} 1 / 2=3 \mathrm{~min})$ and accelerated by the availability of native insulin. In hepatocytes preincubated with insulin, binding was measured after $30 \mathrm{~min}$ incubation in the absence of hormone which allowed the liberation of most $(95 \%)$ of the bound insulin. No modification of insulin binding was observed over extended periods $(2-24 \mathrm{~h})$ of exposure to $10 \mathrm{nmol} / 1$ insulin, when the glycogenic effect of insulin showed striking variations, notably a cessation of the effect between 4 and $12 \mathrm{~h}$. Thus the time-dependence of the glycogenic effect of insulin cannot be related to a defect in insulin binding in cultured fetal hepatocytes.

Key words: Insulin receptors, glycogen, cultured hepatocytes, fetal rat liver, insulin.

It is interesting to study the relationship between binding and the biological effect of insulin as a function of the time of exposure to the hormone. Many studies have concentrated on the early cellular responses [1-5] but prolonged exposure may also induce modifications of insulin binding and hormone-mediated effects. Down regulation of insulin receptor concentration was first described in IM-9 lymphocytes [6] and a decrease in insulin sensitivity was found to be associated with an insulin-induced decrease in hormone binding in fat pad explants [7, 8]. These observations required long-term experiments with insulin-responsive cells. In cultured fetal rat hepatocytes grown for 2-3 days in the presence of cortisol, insulin produced a clear and rapid stimulation of glycogenesis at physiological concentrations of glucose $[9,10]$. This stimulation was modified by the time of contact of the hepatocytes with insulin [10]. Since we are dealing with a homogeneous population of hepatocytes [11], measurements can also be made of their insulin binding characteristics. We have therefore used this cultured fetal hepatocyte model to investigate the relationship between insulin binding and hormonal response, not only after the initial glycogenic effect of insulin but also after prolonged exposure to the hormone.

\section{Materials and Methods}

\section{Culture Procedure}

Primary cultures of hepatocytes were obtained from 18 day-old rat fetuses (Sprague-Dawley) by a method already described [11]. Dissociation of the cells was performed by mild trypsinization. The cells were then plated on a collagen substrate to which only the hepatocytes adhered, and after $18 \mathrm{~h}$ the non-adhering haemapoietic cells were removed. The hepatocytes were grown for up to 3 days. The composition of the medium was as follows: medium NCTC 109 [12], 90 parts; fetal calf serum, 10 parts; cortisol $(10 \mu \mathrm{mol} / 1)$. Fetal calf serum was obtained from Sorga (batch 76-16). Glucose concentration in fresh medium was $1.05 \mathrm{mg} / \mathrm{ml}$. The culture medium ( $2 \mathrm{ml} /$ dish) was replaced after $18 \mathrm{~h}$ and supplemented with $20 \mu \mathrm{l}$ of a $25 \mathrm{mg} / \mathrm{ml}$ glucose solution; the glucose concentration was thus maintained within a range of 0.8 to $1.05 \mathrm{mg} / \mathrm{ml}$ during the 3 -day culture period. This procedure assured good reproducibility among the 300 culture dishes obtained from the same initial cell suspension prepared with 50 fetal livers. When measuring the protein content of the dishes, our coefficient of variation was $3 \%$. All the experiments were performed after 3 days of culture in presence of cortisol (or after 2 days when stated), a stage when the glycogenic effect of insulin is fully expressed [9]. 

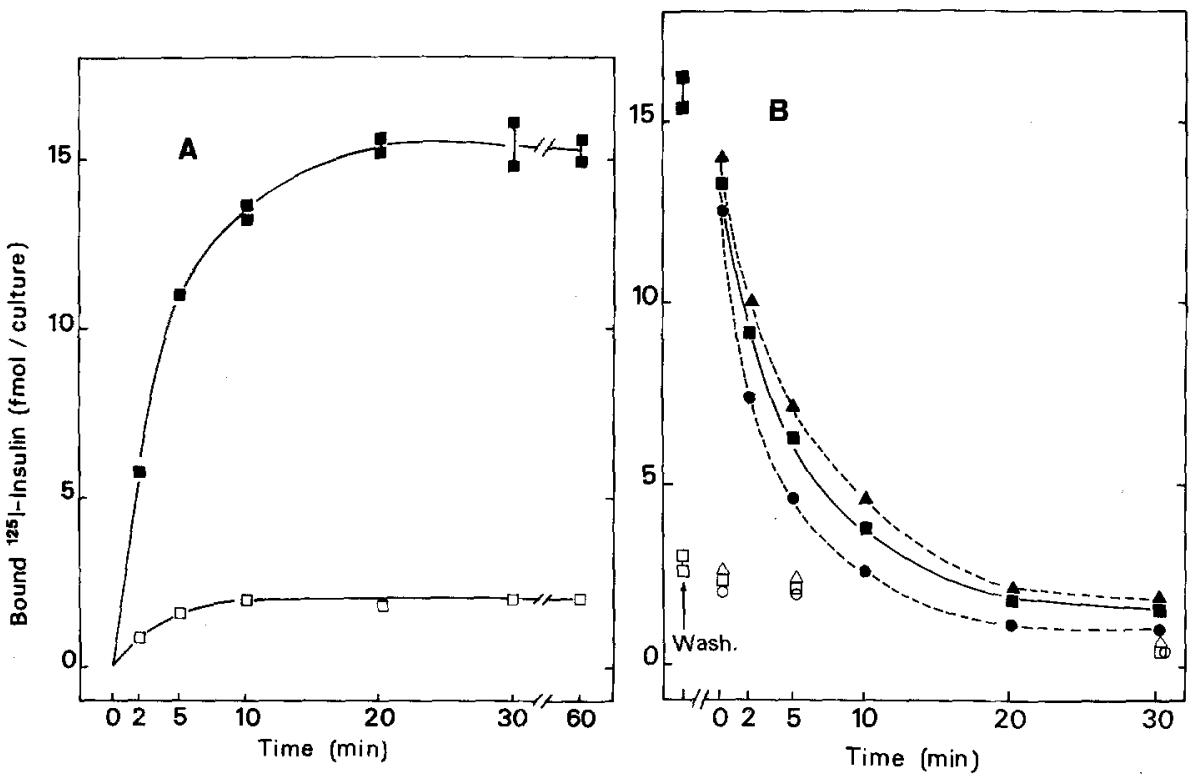

Fig. $1 \mathrm{~A}$ and $\mathrm{B}$. Association and dissociation of ${ }^{125}$ I-insulin in cultured fetal hepatocytes. A Hepatocytes were first incubated at $37^{\circ} \mathrm{C}$ for the times indicated with ${ }^{125} \mathrm{I}$-insulin in the absence $(\boldsymbol{\square}, \boldsymbol{\Lambda}, \boldsymbol{\theta}=$ total binding) or the presence of $10 \mu \mathrm{mol} / 1$ insulin $(\square, \triangle, O=$ non-specific binding). B After $30 \mathrm{~min}$, the hepatocytes were washed with unlabelled medium, then replaced at $37^{\circ} \mathrm{C}$ (time zero of the experiment) in culture medium devoid of native insulin $(\boldsymbol{\Delta}, \Delta)$ or containing $1 \mathrm{nmol} / 1$ $(\boldsymbol{\square}, \square)$ or $10 \mu \mathrm{mol} / 1(\mathbf{Q}, 0)$ insulin. After various incubation times indicated in the abscissa, the amount of bound insulin was determined as described in Methods. Each culture represents $1.1 \times 10^{6}$ hepatocytes in $2 \mathrm{ml}$ of culture medium

\section{Binding Studies}

Porcine monocomponent insulin, both native and radioiodinated at $20-30 \mathrm{Ci} / \mathrm{g}$ was supplied by Novo Research Institute, Copenhagen. The degree of iodination was $0.2-0.4$ atoms of iodine per insulin monomer. Hepatocytes (about $1.1 \times 10^{6}$ per culture) were incubated in $2 \mathrm{ml}$ of culture medium ( $\mathrm{pH} \mathrm{7.3)}$ ) at $37^{\circ} \mathrm{C}$ in the presence of ${ }^{125} \mathrm{I}$-insulin. Parallel cultures received ${ }^{125} \mathrm{I}$-insulin plus an excess of native insulin ( $10^{4}$ times excess). After a given incubation time, the medium was removed and the cultures washed four times with $2.5 \mathrm{ml}$ of ice-cold Hanks solution. This washing step was achieved within $12 \mathrm{~s}$. Cell material was extracted with $0.7 \mathrm{ml}$ of $0.5 \mathrm{~mol} / 1 \mathrm{NaOH}$ for $30 \mathrm{~min}$ at $75^{\circ} \mathrm{C}$. The dishes were then rinsed with $0.7 \mathrm{ml}$ of $0.5 \mathrm{~mol} / 1 \mathrm{HCl}$. Both extracts were pooled and their radioactivity measured with a gamma counter at $75 \%$ efficiency. The amount of cell bound radioactivity in the presence of ${ }^{125}$ I-insulin represents the "total binding". In the presence of excess native insulin, the residual cell bound radioactivity was referred to as "non-specific binding". "Specific binding" is the difference between total binding and non-specific binding. All are expressed as fmol bound ${ }^{125} \mathrm{I}$-insulin per culture. In order to obtain the number of sites occupied per hepatocyte for a given insulin concentration, the amount of specifically bound insulin per hepatocyte (expressed in mol) was multiplied by $6.023 \times 10^{23}$. After various incubation times, the radioactivity in the culture medium was analysed for insulin degradation using $10 \%(\mathrm{w} / \mathrm{v})$ trichloroacetic acid. The soluble radioactivity was expressed as percentage total radioactivity. The value of ${ }^{125} \mathrm{I}$-insulin degradation when incubated in fresh medium without cells $(3 \%)$ was subtracted from degradation values obtained in the presence of cells.

\section{Glycogen studies}

Glycogen labelling in the presence of ${ }^{14} \mathrm{C}$-glucose was determined as previously described [11]. ${ }^{14} \mathrm{C}$-glucose measurements in the presence and absence of insulin have been shown in agreement with the change of glycogen content [10]. To determine the insulin effect, ${ }^{14} \mathrm{C}$-glucose was added to the culture medium at a final activity of $1 \mu \mathrm{Ci} / \mathrm{mg}$ of glucose together with insulin at varying concentrations, or its solvent $(10 \mu \mathrm{mol} / 1 \mathrm{HCl})$. The radioactivity in glycogen was measured after various time intervals. Results are expressed per $10^{6}$ hepatocytes, counting of hepatocytes being performed on parallel cultures [11].

\section{Definitions}

In order to express the insulin response, a "stimulation index" was used, defined as the following ratio: c.p.m. $/ 10^{6}$ hepatocytes in treated cultures divided by c.p.m. $/ 10^{6}$ hepatocytes in control cultures. For each protocol, at least three experiments were performed using different cell preparations. Data are presented as means \pm SEM and the number of experiments (n). Except when stated every symbol (on graphs) or value (in Tables) corresponds to a different culture dish.

\section{Results}

\section{Kinetics}

Labelled insulin $(1 \mathrm{nmol} / \mathrm{l})$ was first allowed to associate with cultured fetal rat hepatocytes at $37^{\circ} \mathrm{C}$. Figure $1 \mathrm{~A}$ shows that the binding of the hormone occurred very rapidly and reached a steady state by 10-20 min. The proportion of labelled insulin bound to the hepatocytes was then $0.75 \%$. In the presence of an excess of unlabelled insulin, ${ }^{125} \mathrm{I}$-insulin binding (non-specific) represented $14 \%$ of the total binding and did not increase with time. After $30 \mathrm{~min}$, when steady-state binding conditions were reached, the hepatocytes were washed, and the dissociation of previously bound ${ }^{125} \mathrm{I}$-insulin determined in the absence and presence of unlabelled hormone. Figure $1 \mathrm{~B}$ shows that binding of ${ }^{125} \mathrm{I}$-insulin was largely and rapidly reversible. When dissociation was allowed in the presence of $1 \mathrm{nmol} / 1$ unlabelled insulin, an insulin concentration identical to that used during the association phase, $50 \pm 2 \%(\mathrm{n}=5)$ of insulin was liberated from its specific sites within 3 min and $94 \pm 2 \%$ $(\mathbf{n}=5)$ after $20 \mathrm{~min}$. The dissociation curve levelled off after $20 \mathrm{~min}$. The dissociation rate of insulin from hepatocytes was accelerated by availability of 
unlabelled insulin. After $5 \mathrm{~min}$ of incubation, the percentage of dissociation was $64 \pm 2 \%$ in the absence of insulin, $71 \pm 3 \%$ and $83 \pm 4 \%(n=5)$ in the presence of $1 \mathrm{nmol} / \mathrm{l}$ and $10 \mu \mathrm{mol} / \mathrm{l}$ insulin, respectively. After $30 \mathrm{~min}$, in the absence or presence of native insulin, this percentage was over $90 \%$.

Insulin degradation during the incubation of hepatocytes $\left(1.2 \times 10^{6}\right.$ hepatocyles in $2 \mathrm{ml}$ of medium) at $37^{\circ} \mathrm{C}$ was determined by trichloroacetic acid precipitation of intact ${ }^{125} \mathrm{I}$-insulin in the medium. The percentage of insulin degradation increased linearly as a function of time and was lowered when the concentration of insulin increased (Table 1). After $30 \mathrm{~min}$, a time chosen for the estimation of specific binding at steady-state in all experiments, the degradation of insulin, low for $1 \mathrm{nmol} / 1^{125} \mathrm{I}$-insulin $(1.5 \pm$ $0.4 \% ; \mathrm{n}=5$ ), was not detectable for $10 \mathrm{nmol} / \mathrm{l}^{125} \mathrm{I}$ insulin. Thus, specific binding will not take into account insulin degradation in this paper.

The stimulatory effect of insulin on glycogen synthesis (estimated by ${ }^{14} \mathrm{C}$-glucose incorporation into glycogen) and ${ }^{125} \mathrm{I}$-insulin binding were investigated in parallel cultures using $10 \mathrm{nmol} / \mathrm{l}$ insulin, a dose previously shown to have a maximal glycogenic effect [10]. The stimulatory effect of insulin was found to be significant after $45 \mathrm{~min}$ '(stimulation index $1.81 \pm 0.21 ; \mathrm{n}=5$ ) and to increase gradually thereafter (Fig. 2). It reached a maximal value after $3 \mathrm{~h}$ (stimulation index $3.50 \pm 0.43 ; \mathrm{n}=5$ ). Figure 2 shows that steady-state binding conditions were obtained as early as after $10 \mathrm{~min}$, which was largely before the glycogenic effect of insulin became significant.

\section{Specificity}

When binding of $1 \mathrm{nmol} / 1^{125} \mathrm{I}$-insulin was measured in the presence of increasing concentrations of unlabelled peptide hormones, both insulin and proinsulin inhibited ${ }^{125} \mathrm{I}$-insulin binding whereas glucagon was virtually without effect (Fig. 3). For $50 \%$ inhibition of ${ }^{125}$ I-insulin binding, a proinsulin concentration of $0.15 \mu \mathrm{mol} / 1$ was needed, which was 30 times higher than the figure for insulin $(0.005 \mu \mathrm{mol} / \mathrm{l})$. High concentrations of both proinsulin and insulin $(10 \mu \mathrm{mol} / \mathrm{l})$ displaced $87 \%$ of insulin, the residual being referred to as non-specific binding. The maximal stimulation of glycogen synthesis was similar with insulin and proinsulin, and the half-maximal responses were obtained with $0.3 \mathrm{nmol} / 1$ insulin and $15 \mathrm{nmol} / 1$ proinsulin respectively.

\section{Concentration Dependence}

Insulin binding at steady state was also measured using concentrations of insulin varying from 0.1 to $30 \mathrm{nmol} / \mathrm{l}$. The amount of ${ }^{125}$ I-insulin specifically bound increased rapidly between 0.1 and $10 \mathrm{nmol} / \mathrm{l}$
Table 1. Insulin degradation in the culture medium. Hepatocytes ( $1.1 \mathrm{million} / \mathrm{culture}$ ) were incubated at $37^{\circ} \mathrm{C}$ in $2 \mathrm{ml}$ of culture medium with respectively $0.3,1$ or $10 \mathrm{nmol} / 1{ }^{12} \mathrm{I}$-insulin. At the times indicated, the amount of ${ }^{125} \mathrm{I}$-insulin present in the medium and precipitable by $10 \%$ trichloroacetic acid was determined as described in Methods and is expressed as percentage of total labelled medium insulin

\begin{tabular}{|c|c|c|c|c|}
\hline \multirow{2}{*}{$\begin{array}{l}\text { Time } \\
(\min )\end{array}$} & & \multicolumn{2}{|c|}{${ }^{125}$ I-insulin concentration } & \multirow[b]{2}{*}{$(10 \mathrm{nmol} / \mathrm{l})$} \\
\hline & & $(0.3 \mathrm{nmol} / 1)$ & $(1 \mathrm{nmol} / 1)$ & \\
\hline & & $\%$ & $\%$ & $\%$ \\
\hline 20 & Fixp. 1 & - & 1.2 & not detectable \\
\hline \multirow{2}{*}{30} & $\int$ F:xp. 1 & 2.2 & 1.6 & not detectable \\
\hline & F:xp. 2 & 2.3 & 1.7 & - \\
\hline 40 & rixp. 1 & - & 3.1 & 0.2 \\
\hline \multirow{2}{*}{240} & $\int$ Fxp. 1 & - & 18.0 & 4.1 \\
\hline & $\{$ lixp. 2 & - & 18.3 & 4.5 \\
\hline
\end{tabular}

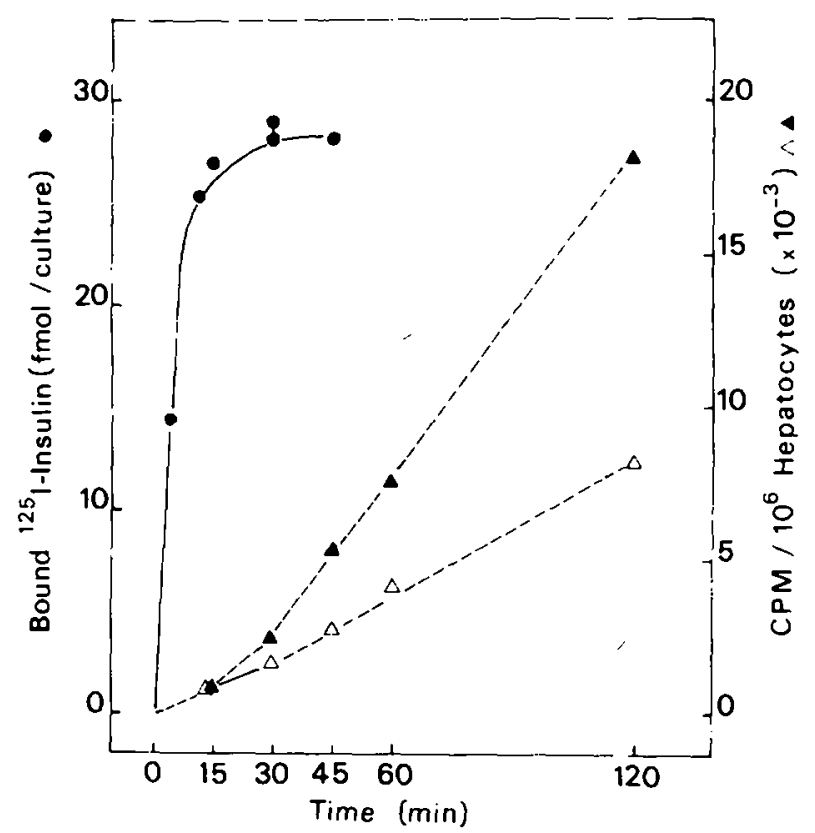

Fig. 2. Early biological effect of insulin and insulin binding. At day 3 of the culture (time zero of the experiment), $10 \mathrm{nmol} / 1$ insulin $(\Delta)$ or its solvent $(\triangle)$ was added together with ${ }^{14} \mathrm{C}$-glucose $(1 \mu \mathrm{Ci} /$ $\mathrm{mg}$ ) and the radioactivity present in glycogen was followed for $2 \mathrm{~h}$. In parallel cultures, the specific binding of insulin was determined using the same concentration of the hormone (0)

and apparent maximal binding occurred with a concentration of $30 \mathrm{nmol} / 1{ }^{125} \mathrm{I}$-insulin (Fig. 4). At this concentration, the amount of hormone bound ( 39.8 $\pm 2.0 \mathrm{fmol} /$ culture; $\mathrm{n}=6$ ) represents about 24,000 bound molecules per hepatocyte. When the data, expressed as the ratio of bound (B) to free (F) insulin, were plotted against the concentration of bound insulin, according to the method of Scatchard, the resulting plot appeared to be curvilinear upwards (Fig. 4, inset). Both insulin binding and stimulation of glycogen synthesis by insulin were determined in parallel cultures using the same source of insulin at 
various concentrations. Because of the different time courses of both processes, shown in Fig. 2, insulin binding and glycogen synthesis were respectively measured after $30 \mathrm{~min}$ and $4 \mathrm{~h}$ of contact with insulin. Half-maximal stimulation of glycogen synthesis was observed with $0.3 \mathrm{nmol} / 1$ insulin when 2,900 sites per hepatocyte were occupied and maximal response was achieved with $10 \mathrm{nmol} / \mathrm{l}$ insulin $(16,000$ sites/hepatocyte) (Fig. 5).

\section{Prolonged Exposure to the Hormone}

Experiments were performed to examine both insulin binding and the stimulatory effect of insulin on ${ }^{14} \mathrm{C}$ glucose incorporation into glycogen in cultures grown up to $24 \mathrm{~h}$ in the presence of $10 \mathrm{nmol} / \mathrm{l}$ insulin. Insulin binding was determined using the following protocol. After a set preincubation period with $10 \mathrm{nmol} / 1$ insulin, the hepatocytes were washed twice and incubated in an insulin-free medium for $30 \mathrm{~min}$; the specific binding was then measured. Control cultures, not preincubated with insulin, were given $10 \mathrm{nmol} / 1$ insulin just before the washing step in order to eliminate any possible effect of carry-over of insulin. Washings and short incubation in the absence of insulin allowed the release of most specifically bound insulin; in hepatocytes preincubated with $10 \mathrm{nmol} / 1$ insulin for $4 \mathrm{~h}, 96 \pm 2 \%(\mathrm{n}=4)$ insulin was liberated from its specific sites after the dissociation step. These hepatocytes bound as much insulin as did controls at ${ }^{125} \mathrm{I}$-insulin concentrations ranging from 0.1 to $1 \mathrm{nmol} / 1$ (Fig. 6). No significant modification of specific binding was observed after preincubation of hepatocytes with $10 \mathrm{nmol} / 1$ between 4 and $24 \mathrm{~h}$

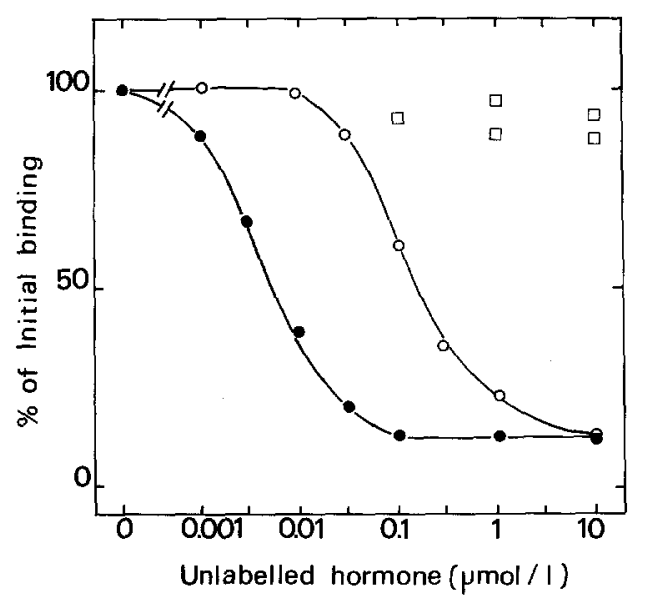

Fig. 3. Inhibition of ${ }^{125} \mathrm{I}$-insulin binding to cultured fetal hepatocytes by unlabelled peptide hormones. Hepatocytes $\left(1.4 \times 10^{6} /\right.$ culture) were incubated in $2 \mathrm{ml}$ of culture medium at $37^{\circ} \mathrm{C}$ for $30 \mathrm{~min}$ with $1 \mathrm{nmol} / \mathrm{l}^{125} \mathrm{I}$-insulin alone (initial binding) and with $1 \mathrm{nmol} / 1^{125} \mathrm{I}$-insulin plus native insulin ( ), or proinsulin $(O)$, or glucagon $(\square)$ at the concentrations indicated. Binding is expressed as percentage of ${ }^{125} \mathrm{I}$-insulin initial binding

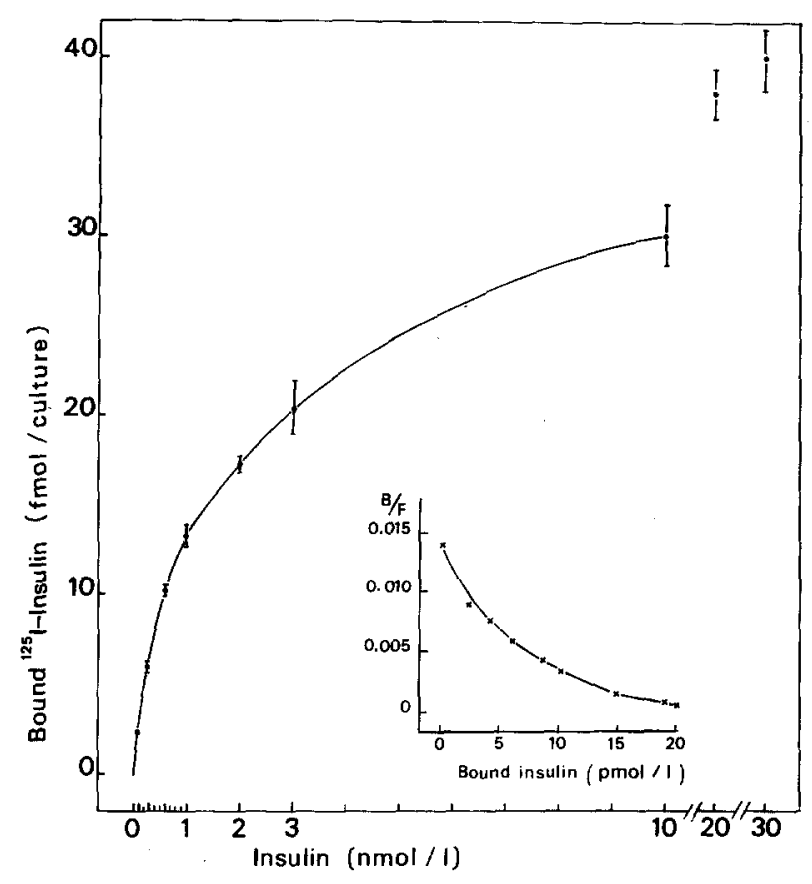

Fig. 4. Binding of insulin as a function of the hormone concentration. Hepatocytes $\left(1.1 \times 10^{6} /\right.$ culture $)$ were incubated in $2 \mathrm{ml}$ of culture medium at $37^{\circ} \mathrm{C}$ for $30 \mathrm{~min}$ in the presence of increasing concentrations of ${ }^{125} \mathrm{I}$-insulin (from 0.1 to $30 \mathrm{nmol} / \mathrm{l}$ ). The specific binding was measured at each hormone concentration and used to calculate absolute amount of bound hormone. Each point is the mean of six separate experiments \pm SEM. Inset: Scatchard plot of the binding data

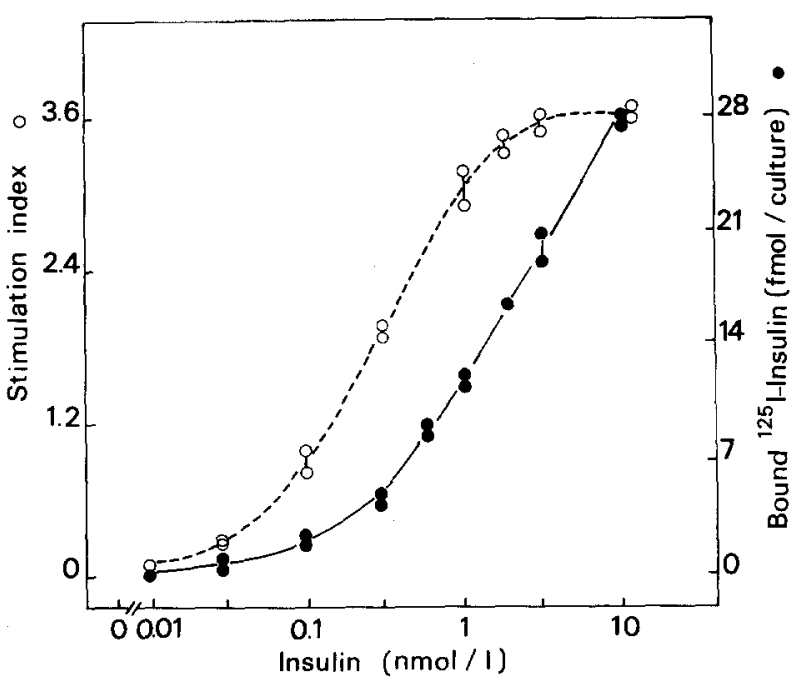

Fig. 5. Relationship between dose-response curves of insulin binding and insulin effect in cultured fetal hepatocytes. At day 3 of the culture, varying concentrations of ${ }^{125} \mathrm{I}$-insulin indicated in the abscissa or its solvent were added together with ${ }^{14} \mathrm{C}$-glucose $(1 \mu \mathrm{Ci} /$ $\mathrm{mg}$ ) and the radioactivity present in glycogen determined after $4 \mathrm{~h}$. The insulin response is expressed using a "stimulation index" defined as the following ratio: $\mathrm{cpm} / 10^{6}$ hepatocytes in treated cultures divided by cpm $/ 10^{6}$ hepatocytes in control cultures $(O)$. Using identical concentrations of the hormone, the specific binding was determined in parallel cultures as described in Figure $4(\bullet)$ 


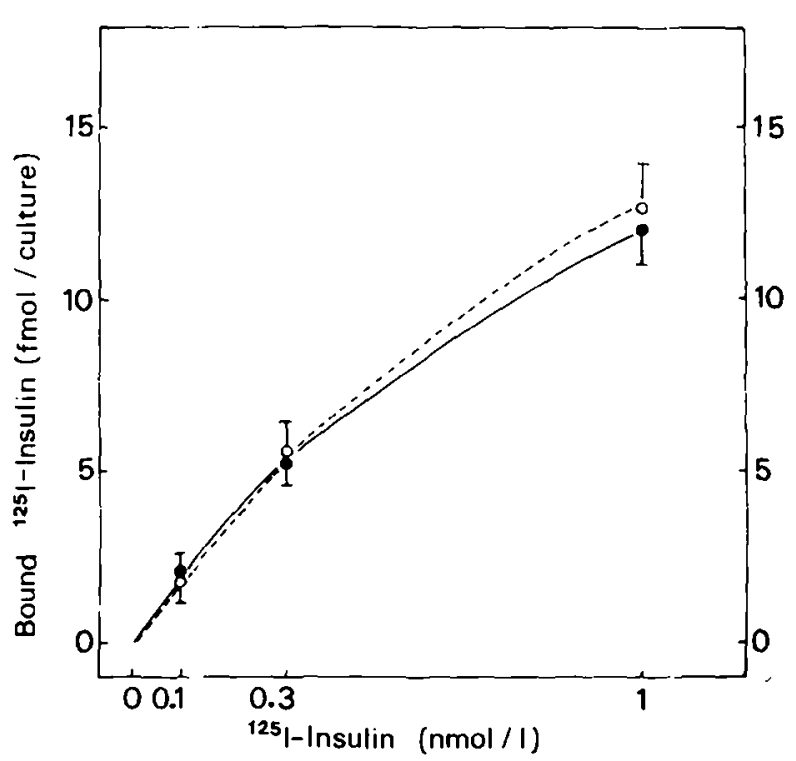

Fig. 6. Binding of insulin to hepatocytes preincubated with insulin for $4 \mathrm{~h}$. Hepatocytes were preincubated for $4 \mathrm{~h}$ in the presence of $10 \mathrm{nmol} / \mathrm{l}$ insulin or its solvent. Then the hepatocytes were washed twice with insulin-free medium and incubated under these conditions for $30 \mathrm{~min}$. Measurements of hormone binding were then performed as described in Fig. 4 , in the presence of $0.1,0.3$ and $1 \mathrm{nmol} / \mathrm{I}^{125} \mathrm{I}$-insulin respectively, in hepatocytes which had been preincubated with $10 \mathrm{nmol} / \mathrm{l}$ insulin $(\bullet)$ or not $(O)$. In these control cultures, $10 \mathrm{nmol} / \mathrm{l}$ insulin was added just before the washing step. Each point is the mcan of four separate experiments \pm SEM

(Fig. 7). After $24 \mathrm{~h}$, for example, the amount of ${ }^{125} \mathrm{I}$ insulin specifically bound at a concentration of $1 \mathrm{nmol} / \mathrm{l}$ was $12.7 \pm 0.6$ and $13.1 \pm 0.5 \mathrm{fmol} /$ culture in preincubated and control hepatocytes respectively $(n=6)$. In parallel cultures incubated in the continued presence of $10 \mathrm{nmol} / \mathrm{l}$ insulin, a clear stimulatory effect on ${ }^{14} \mathrm{C}$-glucose incorporation was observed during the first $4 \mathrm{~h}$; this effect was then diminished over the period from 4 to $8 \mathrm{~h}$ and ceased between 8 and $12 \mathrm{~h}$. It reappeared, but to a lesser extent, after $20 \mathrm{~h}$ (Fig. 7). This transitory cessation of the insulin effect has previously been shown not to be due to hormone inactivation in the medium, since a second $10 \mathrm{nmol} / 1$ dose of insulin did not significantly modify glycogen synthesis [10]. No modification in specific binding could be correlated with these time variations in the glycogenic effect of insulin.

\section{Discussion}

\section{Insulin Binding and the Early Hormonal Response}

Insulin binding and glycogenesis were both measured in hepatocytes from 18-day old rats under physiological conditions $\left(37^{\circ} \mathrm{C}, \mathrm{pH} 7.3\right)$. When these cells were grown for 3 days in the presence of cortisol they

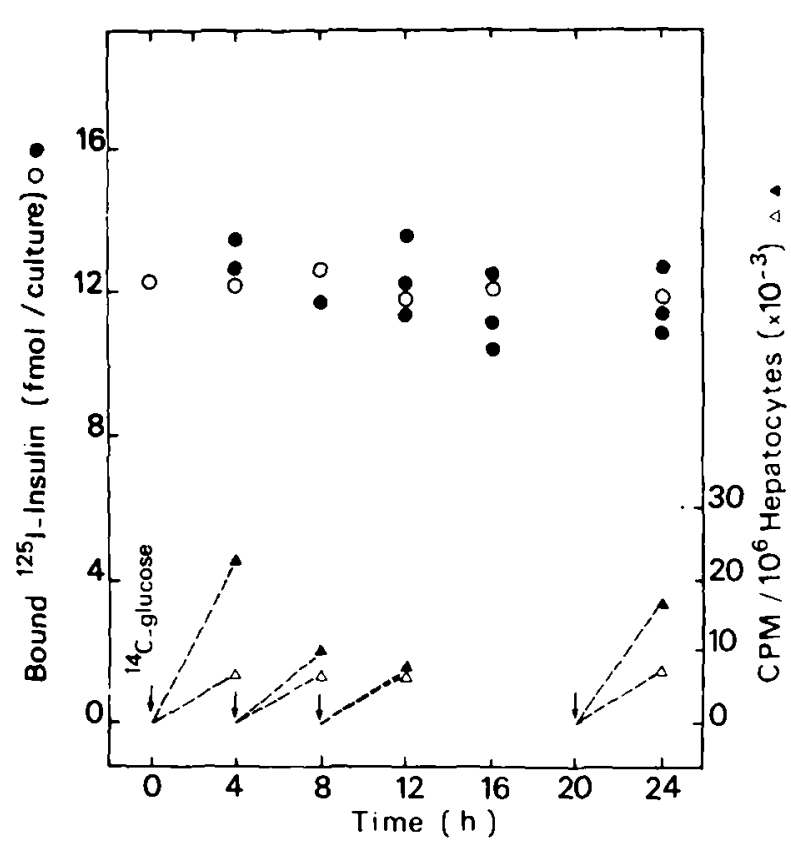

Fig. 7. Insulin binding and insulin effect as a function of time of preincubation of hepatocytes with insulin. Hepatocytes were preincubated in the presence of $10 \mathrm{nmol} / 1$ insulin $(\mathbf{A}, \mathbf{A})$ or its solvent $(O, \Delta)$ for various times as indicated on the abscissa. Measurements of hormone binding were then performed as described in Fig. 6 in the presence of $1 \mathrm{nmol} / \mathrm{l}^{125} \mathrm{I}$-insulin $(\bullet, 0)$. The radioactivity present in glycogen after a 4-h incubation period in the presence of ${ }^{4} \mathrm{C}$-glucose $(1 \mu \mathrm{Ci} / \mathrm{mg})$ was determined in parallel cultures $(\boldsymbol{\Delta}, \Delta)$

showed a clear biological response to insulin (glycogenesis was stimulated 3.5 times after $3 \mathrm{~h}$ ), which was already significant after $45 \mathrm{~min}$ [10]. The cortisol-dependent cell maturation is fundamental if one is to obtain this glycogenic effect of insulin in explants [13], as well as in cultured hepatocytes [9] from fetal rat liver. Insulin binding could be assessed without an insulin degradation inhibitor because fetal hepatocytes only caused minimal insulin degradation in the medium (Table 1). The reason why this should be lower than in cultured adult hepatocytes [14] is not known. It may be related to the low proportion of damaged cells [15] and/or is a characteristic of the fetal stage of the cells. This might be due to the presence of protease activities in fetal liver membranes which could be different from those found in the adult [16]. The insulin binding is hormone specific and the reduced affinity of proinsulin for the receptor of insulin corresponds closely to the lower potency of proinsulin (Fig. 3). Also the data presented in this study, as in other studies performed on adult hepatocytes $[14,15,17-20]$ concern "specific binding", which represents specific cell associated radioactivity. Apparent maximal binding occurred with a hormone concentration of $30 \mathrm{nmol} / \mathrm{l}$ (Fig. 4), which corresponds to 24,000 insulin bound molecules per 
hepatocyte. This number of specific receptor sites per cell is close to [15], or lower than [21], that found in isolated adult hepatocytes. It must be pointed that partially purified fetal liver membranes bind less well than those obtained from the adult [22]; this would suggest an increase in the number of insulin receptors during development.

Maximal stimulation of glycogenesis occurred with $10 \mathrm{nmol} / 1$ insulin while ${ }^{125} \mathrm{I}$-insulin binding corresponded to $70 \%$ of the apparent maximal binding (measured at $30 \mathrm{nmol} / 1$ insulin). Half-maximal response was obtained with $0.3 \mathrm{nmol} / 1$ insulin when $13 \%$ of the "total" number receptor sites were occupied (Figs. 4 and 5). In isolated adipocytes, a maximal response to insulin for several parameters was achieved with only a minority of hormone-filled receptor sites $(5-10 \%)[1,3]$. By contrast, a close correlation has been seen between insulin binding and stimulation of aminoacid uptake in both isolated adult hepatocytes [4] and thymocytes [2]. In isolated soleus muscle, a maximal stimulation of 2-deoxyglucose uptake by insulin has been found to occur when only $20 \%$ of the total receptors were occupied. Moreover, the concentration dependence of several biological effects was different [5]. In particular, the relationship between insulin binding and glycogenesis, an effect rather distal to insulin-receptor interaction, appeared to be similar to that described in cultured fetal hepatocytes.

The rate of dissociation of insulin from its specific sites is rapid and accelerated by the presence of unlabelled hormone in the medium at $37^{\circ} \mathrm{C}$ (Fig. 1B). In isolated adult hepatocytes, the rate of dissociation of insulin has been found to be accelerated by the addition of native insulin at $12{ }^{\circ} \mathrm{C}$, but not at $37^{\circ} \mathrm{C}$ [15]. Accelerated dissociation of cell-bound insulin by the availability of free insulin is particularly marked below $20^{\circ} \mathrm{C}$ and has been interpreted in terms of "negative cooperativity" among insulin receptors [23]. This means that as the fractional receptor occupancy increases, the affinity of the receptors decreases (faster dissociation rate) owing to site-site interactions. The insulin binding is largely reversible (Fig. 1 B), just as in isolated adult hepatocytes $[15,17]$. Whatever the time of the previous exposure most of insulin was liberated from its specific receptor sites after a $30 \mathrm{~min}$ incubation period in hormone-free medium. This allowed insulin binding in insulin-treated hepatocytes to be measured.

\section{Insulin Binding and the Time Dependent Hormonal Response}

A negative regulation of insulin receptor concentration on the cell after prolonged exposure to the hor- mone has been observed in IM-9 lymphocytes [6] and found to be hormone-specific [24]. This receptor down regulation process has not been observed in 3T3-L1 fibroblasts $[25,26]$ which are target cells for insulin, but it has been described in cultured adult hepatocytes [14] and RL-PR-C hepatocytes [27]. It was not found in this study carried out with cultured fetal hepatocytes, where no modification of insulin binding could be observed after prolonged preincubation of cells with $10 \mathrm{nmol} / \mathrm{l}$ insulin (Figs. 6 and 7). The down regulating effect of insulin might result from an imbalance between the rate of internalisation of the insulin receptor complex and that of reinsertion of newly synthesised, and possibly recycled receptors into the plasma membrane [28]. In the fetal hepatocyte, receptor down regulation may not be seen because of some characteristic of the fate of receptors in the cell, e. g. rapid turnover of the insulin receptor sites. More work will be needed to resolve these differences.

In genetically obese-hyperglycaemic rodents, hyperinsulinaemia has been found to be associated with decreased concentration of insulin receptors in several types of cells and loss of sensitivity to exogenous insulin [21]. However when hyperinsulinaemia in ob/ob mice was normalised by fasting or by streptozotocin treatment, there was an apparent lack of direct relationship between insulin binding and insulin effects in liver and adipose tissue, but in muscle both variables changed in parallel [29]. Besides, in $\mathrm{fa} / \mathrm{fa}$ rats, the insulin resistance of muscle, whose insulin binding is barely altered, can be ascribed principally to defects that are located beyond the insulinreceptor interaction [30]. In IM-9 lymphocytes, the physiological significance of the decrease in insulin binding is questionable because these cells have not been shown to give specific insulin biological responses [31]. In explants from epididymal fat pads, a decrease in insulin sensitivity has been observed after prolonged exposure to insulin [7], which can be related to a decrease in specific binding at low concentrations of the labelled hormone [8]. Prolonged exposure of cultured fetal hepatocytes to $10 \mathrm{nmol} / 1$ insulin modifies the stimulatory effect of insulin on net glycogen synthesis with, in particular, cessation of the early insulin effect between 4 and $12 \mathrm{~h}[10]$. This transient cessation of the insulin effect is not linked to any modification of insulin binding (Figs. 6 and 7). It could be caused by a defect located somewhere along the insulin-stimulated glycogenic pathway and/ or by the occurrence of an antagonistic regulation via stimulation of glycogenolysis [10]. In conclusion, cultured fetal hepatocytes allow direct correlation studies to be made between changes in insulin-mediated functions and in receptor binding, and ultimately on the fate of insulin in the cell. This study 
shows a lack of relationship between the time dependence of the glycogenic effect of insulin and specifically cell-associated insulin.

Acknowledgements. The authors wish to thank Dr. M. A. Devynck for many helpful suggestions in binding studies. This research work, which is taken from a Diplôme de l'Ecole Pratique des Hautes Etudes submitted by P. Menuelle, was supported by Délégation Générale à la Recherche Scientifique, grant 77.7.1275 and by Institut National de la Santé et de la Recherche Médicale, grant 74.79.106.

\section{References}

1. Kono T, Barham FW (1971) The relationship between the insulin-binding capacity of fat cells and the cellular response to insulin. Studies with intact and trypsin-treated fat cells. J Biol Chem 246: 6210-6216

2. Goldfine ID, Gardner JD, Neville DM Jr (1972) Insulin action in isolated rat thymocytes. I. Binding of ${ }^{125}$ I-insulin and stimulation of $\alpha$-aminoisobutyric acid transport. J Biol Chem 247: 6919-6926

3. Gliemann J, Gammeltoft S, Vinten J (1975) Time course of insulin-receptor binding and insulin-induced lipogenesis in isolated rat fat cells. J Biol Chem 250: 3368-3374

4. Le Cam A, Freychet P (1978) Effect of insulin on amino acid transport in isolated rat hepatocytes. Diabetologia 15: $117-123$

5. Le Marchand Y, Jeanrenaud B, Freychet $P$ (1978) Insulin binding and effects in the isolated soleus muscle of lean and obese mice. Am J Physiol 234: E348-E358

6. Gavin JR III, Roth J, Neville DM Jr, De Meyts P, Buell DN (1974) Insulin-dependent regulation of insulin receptor concentrations: A direct demonstration in cell culture. Proc Natl Acad Sci USA 71: 84-88

7. Livingston JN, Purvis BJ, Lockwood DH (1978) Insulindependent regulation of the insulin-sensitivity of adipocytes. Nature 273: 394-396

8. Livingston JN, Purvis BJ, Lockwood DH (1978) Insulin induced changes in insulin binding and insulin-sensitivity of adipocytes. Metabolism 27 [Suppl 2]: 2009-2014

9. Plas C, Nunez J (1976) Role of cortisol on the glycogenolytic effect of glucagon and on the glycogenic response to insulin in fetal hepatocyte culture. J Biol Chem 251: 1431-1437

10. Plas C, Menuelle P, Moncany MLJ, Fulchignoni-Lataud MC (1979) Time dependence of the glycogenic effect of insulin in cultured fetal hepatocytes. Diabetes 28: 705-712

11. Plas C, Chapeville F, Jacquot R (1973) Development of glycogen storage ability under cortisol control in primary cultures of rat fetal hepatocytes. Dev Biol 32: 82-91.

12. Evans VJ, Bryant JC, Kerr HA, Schilling EL (1964) Chemically defined media for cultivation of long-term cell strains from four mammalian species. Exp Cell Res 36: 439-474

13. Eisen HJ, Goldfine ID, Glinsmann WH (1973) Regulation of hepatic glycogen synthesis during fetal development: Roles of hydrocortisone, insulin and insulin receptors. Proc Natl Acad Sci USA 70: 3454-3457

14. Blackard WG, Guzelian PS, Small ME, (1978) Down regulation of insulin receptors in primary cultures of adult rat hepatocytes in monolayer. Endocrinology 103: 548-553

15. Gammeltoft S, Kristensen LO, Sestoft L (1978) Insulin receptors in isolated rat hepatocytes. Reassessment of binding properties and observations on the inactivation of insulin at $37^{\circ} \mathrm{C}$. J Biol Chem 253: 8406-8413
16. Freychet P, Kahn R, Roth J, Neville DM Jr (1972) Insulin interactions with liver plasma membranes. Independence of binding of the hormone and its degradation. J Biol Chem 247: 3953-3961

17. Freychet P, Rosselin G, Rançon F, Fouchereau M, Broer Y (1974) Interactions of insulin and glucagon with isolated rat liver cells. I. Binding of the hormones to specific receptors. Horm Metab Res [Suppl Series] 5: 72-78

18. Olefsky JM, Johnson J, Liu F, Edwards P, Baur S (1975) Comparison of ${ }^{125} \mathrm{I}$-insulin binding and degradation to isolated rat hepatocytes and liver membranes. Diabetes 24: 801-810

19. Terris S, Steiner DF (1975) Binding and degradation of ${ }^{125} \mathrm{I}-$ insulin by rat hepatocytes. J Biol Chem 250: 8389-8398

20. Almira EC, Reddy WJ (1979) Effect of fasting on insulin binding to hepatocytes and liver plasma membranes from rats. Endocrinology 104: 205-211

21. Freychet $P$ (1976) Interactions of polypeptide hormones with cell membrane specific receptors: Studies with insulin and glucagon. Diabetologia 12: 83-100

22. Blazquez E, Rubalcava B, Montesano R, Orci L, Unger RH (1976) Development of insulin and glucagon binding and the adenylate cyclase response in liver membranes of the prenatal, postnatal, and adult rat: Evidence of glucagon "resistance". Endocrinology 98: 1014-1023

23. De Meyts P, Bianco AR, Roth J (1976) Site-site interactions among insulin receptors. Characterization of the negative cooperativity. J Biol Chem 251: 1877-1888

24. Lesniak MA, Roth J (1976) Regulation of receptor concentration by homologous hormone. Effect of human growth hormone on its receptor in IM-9 lymphocytes. J Biol Chem 251: 3720-3729

25. Chang TH, Polakis SE (1978) Differentiation of 3T3-L1 fibroblasts to adipocytes. Effect of insulin and indomethacin on the levels of insulin receptors. J Biol Chem 253: 4693-4696

26. Karlsson FA, Grunfeld C, Kahn CR, Roth J (1979) Regulation of insulin receptors and insulin responsiveness in 3T3-L1 fatty fibroblasts. Endocrinology 104: 1383-1392

27. Petersen B, Beckner S, Blecher M (1978) Hormone receptors. 7. Characteristics of insulin receptors in a new line of cloned neonatal rat hepatocytes. Biochem Biophys Acta 542: 470-485

28. Gorden Ph, Carpentier JL, Freychet P, Orci L (1980) Internalization of polypeptide hormones. Mechanism, intracellular localization and significance. Diabetologia 18: 263-274

29. Le Marchand Y, Loten EG, Assimacopoulos-Jeannet F, Forgue ME, Freychet P, Jeanrenaud B (1977) Effect of fasting and streptozotocin in the obese-hyperglycemic (ob/ob) mouse. Apparent lack of a direct relationship between insulin binding and insulin effects. Diabetes 26: 582-590

30. Crettaz M, Prentki M, Zaninetti D, Jeanrenaud B (1980) Insulin resistance in soleus muscle from obese Zucker rats. Involvement of several defective sites. Biochem $\mathrm{J}$ 186: 525-534

31. Gavin JR III, Gorden P, Roth J, Archer JA, Buell DN (1973) Characteristics of the human lymphocyte insulin receptor. J Biol Chem 248: 2202-2207

Received: February 12, 1980,

and in revised form: September 30, 1980

Dr. C. Plas

UER Odontologie

Université Paris 7

Tour 43-2, place Jussieu

F-75221 Paris Cedex 05

France 